FACTA UNIVERSITATIS

Series: Economics and Organization Vol. 15, $\mathrm{N}^{\mathrm{o}} 3,2018$, pp. 245 - 256

https://doi.org/10.22190/FUEO1803245L

Original Scientific Paper

\title{
FACTORS AFFECTING CUSTOMER LOYALTY IN THE BUSINESS MARKET - AN EMPIRICAL STUDY IN THE REPUBLIC OF SERBIA
}

\author{
UDC 336.1(497.11)
}

\section{Vinko Lepojević, Suzana Đukić}

University of Niš, Faculty of Economics, Serbia

\begin{abstract}
In modern business conditions characterized by the requirements for achieving superior profit margins, customer satisfaction and loyalty have become the basic company business priorities. The ability of the company to achieve a high level of customer loyalty, in conditions of intense competition is determined by delivery of superior quality service, but also by creating a positive overall customer experience with the company. Such a situation implies the relationship development based on the trust and commitment of the buyer to the supplier. The aim of the paper is to investigate the impact of satisfaction, trust, buyer loyalty and perceived quality of services on the level of achieved loyalty. Empirical research was carried out on a sample of small and medium-sized enterprises in order to identify loyal and disloyal customers. Statistical analysis is based on the application of multivariate techniques that enabled simultaneous analysis of the mutual relationship between the identified four independent variables on the dependent variable, i.e. on degree of buyer loyalty.
\end{abstract}

Key words: customers, loyalty, satisfaction, trust, commitment, business market

JEL Classification: M310, M210

\section{INTRODUCTION}

One of the most important problems of perfect marketing theory and practice is how to keep the customer, make him satisfied and loyal for a long period of time. Instead of focusing on attracting new customers and creating transactions, companies are increasingly focusing on delivering superior value to consumers and on building long-

Received May 30, 2018 / Accepted July 04, 2018

Corresponding author: Vinko Lepojević

University of Niš, Faculty of Economics, Trg kralja Aleksandra 11, 18000 Niš, Serbia

E-mail: vinko.lepojevic@eknfak.ni.ac.rs 
term relationships with customers in order to keep them. The retention of existing ones in relation to the conquest of new consumers is conditioned, above all, by intense competitive pressures, visible changes in customer behavior and high cost of acquisitions. Creation of satisfaction and loyalty in such conditions requires the companies to deliver high quality services as the preconditions for developing the trust and loyalty of the buyer (Mital \& Kamakura, 2001). Both learning and feedback with customers are the source of valuable information about their future requirements, shopping intentions and consumption (Paquette, 2006).

The problem of customer retention is noticeable in the business market where the success of a company is limited by a small number of worthy customers, and where the interdependence relationship between sellers and customers is a limiting factor of business success. Being informed and professionalism of business customers, as well as the dominance of rational motives in decision-making process, increase their negotiating strength and power and make difficulties for companies to support long-term loyalty. This has led to a number of theoretical considerations and empirical research on how to achieve consumer loyalty and identify factors that motivate / demotivate such customer behavior.

Starting from the above, the main goal of the paperis to identify and determine the significance of certain factors in order to improve customer loyalty. Starting with the identified factors of loyalty, the research objectives are: customer satisfaction, customer trust and commitment, and importance of perceived quality of service for loyalty enhancement. The work consists of two parts. In the first part of the paper, a literature review of significance and method of customer loyalty insurance is given, while the second part of the paper explains the methodology and presents results of the empirical research, their discussion and reached conclusions.

\section{THEORETICAL BACKGROUNDS}

\subsection{Significance and problems in ensuring customer loyalty}

Ensuring a high level of customer loyalty is one of the most important tasks of modern management. Preference of retaining the existing ones toward winning new customers is conditioned, primarily, by intense competitive pressures, customer demands and high costs to get them. The most effective way to keep buyers in such conditions are to build loyalty by continued assurance of satisfaction and by creating high costs of switching to other brands. Loyal customers are important "assets" of companies and profit generators. A positive relationship between customer loyalty, profit and company's competitive advantage has been confirmed by numerous studies (Kumar \& Shah, 2004; Gruca \& Rego, 2005; Kotler \& Keller, 2007; Kumar et al., 2011). They regularly repeat purchases, often buy a complete line of products and /or services, show lower sensitivity to price changes, tie-up for longer to the company, demonstrate immunity to competition. Increase in profit is the result of lower costs for servicing of existing ones than the costs of getting new customers (Kotler \& Keller, 2007). Loyal customers also show the so-called active loyalty, i.e. they recommend the company and its brands to other customers, which leads to greater business stability, growth and profitability of the company (Diller, 2000; Gruca \& Rego, 2005; Rust \& Ming-Hui, 2014). 
The problems in ensuring customer loyalty in modern business conditions have caused numerous theoretical considerations and empirical research dedicated to identifying the factors which lead to such customer behavior. The starting point in the measurement is the realization of essential loyalty. Satisfaction is a necessary, but not sufficient, requirement of essential customer loyalty. The relationship between satisfaction and loyalty, due to the action of many factors, is complex and not always proportional. The positive attitude of buyers is also not a guarantee of a focal mark repurchasing, if such a decision is more pronounced towards another brand. In order to maintain long-term loyalty, the power of the consumer positive attitude is necessary, and the strong attitude differentiation compared to other brands that shows a tendency towards future behavior (Kumar \& Shah, 2004). This means that the product and/or brand should represent the best alternative choice for the customer to remain loyal. Therefore, customer loyalty measurement is based on a combination of loyalty behavior and loyalty attitude. The behavior of buyers takes a consistent repetition of behavior. Measuring customer attitudes, on the other hand, is based on information about attitudes that reflect the emotional and psychological aspect of loyalty.

Measuring the emotional aspect of customer loyalty emphasizes the importance of factors that imply feeling, committing, trusting. Moorman et al. (1993) consider that the customer's confidence, the involvement of customers in value creation, customer loyalty and perceived quality, are the most important factors that lead to loyalty (Moorman et al., 1993). Kumar et al. (2011) consider that, except trust and affiliation, the great influence on the overall quality of company's relationship with the buyer, has mutual desire to invest in relationship development as well as expectations regarding its duration. Later research by the authors distinguishes customer confidence and commitment as key factors of customer loyalty. Bearing in mind the above, it can be concluded that in the research work, the following factors of customer loyalty have been frequently repeated: customer satisfaction, customer trust, customer commitment and perceived quality of service.

\subsection{Customer loyalty factors}

\subsubsection{Satisfaction of customers}

Customer satisfaction is an essential factor of their loyalty. The customer satisfaction assessment is based on a comparison of the customer's expectations and post-sales perceptions (Kotler \& Keller, 2012). In the meantime, customer satisfaction is the expression of satisfaction or disappointment that arises as a result of the comparison of deliveries and the expectation of value. The result shows that the assessment of the realization of the customer's expectations is individual and can be positive or negative (satisfaction / dissatisfaction). It includes objective and subjective elements related to tangible and intangible aspects of value. It can be based on emotional and rational motives. Kundu \& Datta (2015) state that satisfaction is an affirmative, emotional state that is the result of the process of all aspects of the relationship between the partners.

The impact of satisfaction on business performance, on the other hand, can be viewed from two aspects - behavioral and psychological. The first aspect relies on understanding that customer satisfaction influences the resulting behavior, such as: re-purchase (Trasorras et al., 2009), customer loyalty (Bowen \& Chen, 2015), giving recommendations to others 
(Ulaga \& Eggert, 2006), but also purchase cessation, complaints, negative verbal advertising, in case of lower satisfactory degree of complete dissatisfaction.

The second, psychological aspect of customer satisfaction is emphasizing satisfaction dimension that does not have to be linked to the future behavior of the customer, but to his inner feeling, in terms of "with consuming, the customer fulfills some need, desire, goal, etc. which gives satisfaction". This means that the satisfaction has to be viewed as a predictor of coordination and continuity in the process of relation developing (Ulaga \& Eggert, 2006). Therefore, through the satisfaction and continuity of the relationship, both sides have to develop desire for growth. The presence of both dimensions determines the cumulative satisfaction which is a necessary but not sufficient condition for buyer's loyalty.

Research of business customers satisfaction is complex. The complexity stems from the complexity of the customer decision-making process, the number of people involved in this process, the number of seller-buyer interactions, and factors that influence satisfaction or dissatisfaction and their transition into measurable attributes. Therefore, research of satisfaction in the business market requires inherent complexity and consideration of multiple aspects and different contexts that affect satisfaction as a managerial phenomenon. Dyad relationship between the buyer and the seller must be studied in the context of a larger set of interorganizational relationships that form a complex context of business purchasing. Various forms of cooperation and partnerships in the business market emphasize more complete survey of the satisfaction and the common nature of involved parties. The achieved satisfaction is seen as a cohesive factor or strength in development of further and deeper relations. In case of long-term relationships, the re-purchase situation is at the same time the pre-purchase situation and the buyer will not repeat his purchase if his expectations are not met. High degree of customer satisfaction often creates confidence and commitment between parties in interaction, which increases customer loyalty and duration of relationships. Involving the customer in production performance and other business processes, results in his partial responsibility for his own satisfaction.

Starting from these facts, the traditional method of determining the satisfaction of business customers with the subsequent evaluation of the completed purchase becomes inadequate because it does not reveal the reasons of satisfaction / dissatisfaction. The focus of modern research is overall satisfaction, i.e., overall performance of the supplier. According to one survey, it can be measured by seven dimensions: product satisfaction, strength of sale, product-related information, ordering process, services, interaction with employees, and satisfaction with complaints solving (Ghijsen et al., 2010). In order to ensure a more realistic approach to investigating customer satisfaction, it is necessary to focus on three areas: the internal context of customer and seller relations, the context of the network, and the context of external influences (Tikkanen et al., 2000).

Starting from the above hypothesis, tested $\mathrm{H} 1$ is:

H1: Satisfaction of customers increases their loyalty in the business market.

\subsubsection{Customer trust}

Trust is an important determinant of the buyer's behavior in the purchasing process. It arises as a result of the overall customer experience with the product and the company, and its tangible and intangible attributes. Trust development generates positive attitudes and customer loyalty (Moreira \& Silva, 2015). Trust in brand reduces the customer's 
hesitation in the purchasing process which can arise from factors such as: product complexity, purchasing risk, cognitive dissonance, and high transaction costs. A customer who believes in an enterprise becomes a valuable source of information in the process of value creation. Mutual trust of the buyer and company creates conditions for the exchange of important information in the process of value creation and the construction of a longterm, mutually beneficial relationship. It is therefore considered that confidence is an essential factor that leads to long-term customer retention (Moorman et al., 1993; Anderson \& Mittal, 2016). Lost trust means a lost customer.

Characteristics of trust based relationships are: cooperation between buyer and seller, first-class, long-term relationships and quality of cooperation. Cooperation is based on the fact that trust reduces uncertainty and risk, which increases the cooperation between the supplier and buyer. From relationships based on trust and cooperation, the seller and buyer learn that mutual activities give better effects than reliance on individual ones. Confidence encourages both sides to work to preserve interpersonal relationship and a desire to overcome potential conflicts. Preference is on long-term benefits. The trust between the company and the buyer means that the customer will become more involved in the process of value creation and mutual business, which contributes to lasting relationship. Confidence-based trusts mean quality cooperation and better exchange of information and knowledge, which increases their usefulness. Misunderstandings and conflicts are resolved in an efficient and friendly manner (Morgan \& Huntt, 1994; Moorman et al., 1993; Ndubisi, 2011).

Trust as a factor of loyalty is difficult to understand and anticipate. In order to explain the notion of trust, the majority of authors look for the base in psychology, starting from the partner's belief they will behave in a relationship and act in mutual interest. Such relationships are characterized by: credibility, reliability, intimacy, and self-orientation (Peppers \& Rogers, 2004). The first three components are positive in building trust between the buyer and the seller. The trustworthiness of the partners, delivery of the promised, understanding between them, creation of a pleasant atmosphere and the sense of security, strengthen and enhance trust. Common goals and values, interdependence, communication quality and non-opportunistic behavior are the most important factors on which it depends. Open communication, formal and informal, harmonizes expectations, solves doubts and reduces uncertainty. Relations based on trust, loyalty, cooperation and strength of partners enable us to create values in relationships and to strengthen the competitive advantage of partners (Palmatier, 2008; Ndubisi, 2011). Research of credit cooperatives in Brazil has shown that relations between the strength of partners in a dyad relationship, between buyer and a seller, customer confidence, their commitment and cooperation, largely determines the quality of relationships with a central organization.

On the other hand, self-orientation and self-reliance of partners in relationships means predominance of individual and non-synchronized over synchronized and mutual action. The strength of this component is important, because if the customer feels misunderstanding from the company which works for its own benefit, that causes dishonesty and disobedience and that, on the other hand, reduces trust and loyalty of the buyer.

Bearing in mind the above, the tested hypothesis $\mathrm{H} 2$ is:

$\mathrm{H} 2$ : Trust leads to an increase in customer loyalty in the business market. 


\subsubsection{Consumer commitment}

Relations based on trust between seller and buyer are the basis of mutual attachment creation. Quality communication among buyer and seller, synchronized behavior and mutual work create trust and attachment. Together, both factors directly lead to cooperative behavior, long-term relationships based on loyalty (Morgan \& Hunt, 1994). Creating affection means that for both buyer and seller relations are important and there is a mutual desire to continue and develop them in the future. It is a power that drives participants to continue their cooperation. Relationships built on trust and commitment are a guarantee that the efforts made to maintain and develop relationships in the future will result in mutual benefits. That strengthens trust and commitment, increases customer loyalty and all performances of relationships.

Commitment as a complex factor can be defined from different points of view. The opinion that the psychological component is crucial for creating attachments, which emphasizes emotional loyalty and engagement of the participants in the relationship, prevails. Affective component of loyalty is associated with the long-term orientation of involved parties and with their focus on achieving long-term loyalty and goals, as well as the belief that relations will bring desired results. Such attachment is based on trust, willingness to resolve conflict in a friendly manner, and supports the long-term benefits of relationship. In this sense, the partner behaves in a way he expects from the other side and has confidence in such behavior (Ndubisi, 2011).

Attachment may also arise from the self-interest of a particular party in current relation, as a result of the observed difference between costs and benefits (economic, social and status). In this case, this is so-called prolonged attachment. Normative attachment arises as a result of moral obligations of partners to continue cooperation. The largest number of research connected with the relationship of trust, commitment and loyalty of customers, confirms the high degree of correlation of trust and devotion on the one hand, and retention of customers and future intentions for relationship developing, on the other. Attraction in relationships very often means sensitivity and dependence, which builds relationships that are worthy of the trust of the partner. Continuity of relationships over time motivates companies to work together to achieve goals and mutual benefits. Each side is aware that continued delivery of superior benefits will be valued from the other side, which therefore wants to engage in a relationship.

Starting from the above, the $\mathrm{H} 3$ hypothesis is:

H3: There is a strong correlation between customer loyalty and retail sales.

\subsubsection{Perceived quality of service}

Numerous studies have shown that perceived quality of service is an important determinant of customer satisfaction and loyalty (Lovelock \& Wirtz, 2011; Wilson et al., 2012; Moreira \& Silva, 2015). This influence can be reached through degree of satisfaction, considering that the concept of customer satisfaction and service quality concept are connected, and often they are identifiable. Starting from that point, one can speak of a linear relationship between the quality of service and satisfaction, which means that a higher level of service quality leads to a higher level of customer satisfaction. There is also a perception that the quality of service is not the only determinant of customer satisfaction, even if it is often crucial (Veljković, 2009). According to this opinion, 
besides the quality of services, customer satisfaction is determined also by other elements (quality of the accompanying product, prices, situation factors and personal factors). Research based on such insight did not show a strong correlation between the perceived quality of services from users and their satisfaction, especially when it comes to certain elements of service quality.

The problem of the quality of service measurement comes out from the complexity and multidimensionality of the concept of service quality (Jain \& Gupta, 2004). The service's intangibility is one of the key reasons for this. Therefore, there is no autho's' consent in terms of defining the quality of services. Dominant opinion is that the quality of service comes out from the compliance with customer expectations, i.e., it is the result of their comparison between expectations and their perceptions of services to be provided (Caruna et al., 2000). The emphasis that the overall quality assessment depends on evaluation of the benefits provided by the particular service, and also on the process of its delivery, points to complexity and multidimensionality of the service quality concept. Comparatively, the consent of authors matches the belief of Pollack (2008) that there are three basic elements of service quality: the quality of results (the actual result of service contact), the quality of interaction (estimation of overall customer relationship with the service staff) and the quality of service environment (physical environment where interaction occurs).

Starting from the above, the hypothesis $\mathrm{H} 4$ is:

H4: Perceived quality increases customer loyalty in the business market.

\section{Methodology OF ReSEARCH}

The aim of the research is to examine factors that influence the loyalty of customers. The basic research question for which the empirical research was supposed to provide the answer is: Is there a statistically positive correlation between customer loyalty and loyalty factors - customer satisfaction, trust, customer loyalty and perceived quality of services?

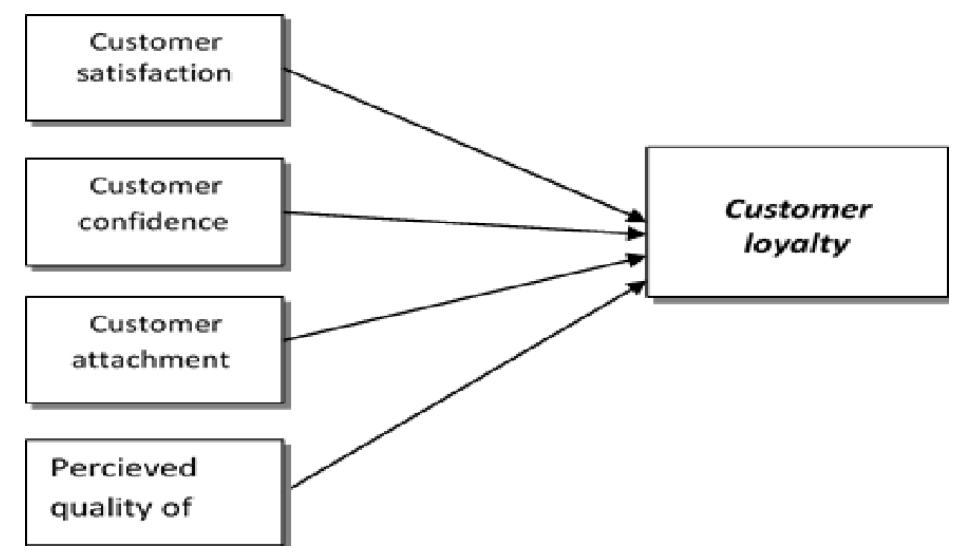

Fig. 1 Model of conditionality of customer loyalty Source: Authors, Adapted to: Rauyruen \& Miller (2007) 
Starting from the set goals, we tried to check the following hypotheses:

H1: Satisfaction of customers increases their loyalty in the business market.

$\mathrm{H} 2$ : Trust leads to an increase in customer loyalty in the business market.

H3: There is a strong correlation between customer loyalty and customer commitment in the business market.

H4: Perceived quality increases customer loyalty in the business market.

In order to identify the significance of each factor of loyalty in the business market, the research used a model that includes four independent variables (customer satisfaction, customer trust, customer commitment, and perceived quality of service) and customer loyalty as a dependent variable (Figure 1).

In order to test the hypotheses, the empirical research was conducted. Respondents' opinions were recorded on the 5-fold Likert scale, where 1 indicates "I do not agree in general", while 5 means "I completely agree" The sample was made up of small, average and big companies i.e.. of small shops, specialized shops and cafes from the territory of southeastern Serbia (Pčinja, Jablanica, Nis, Toplica, Zajecar and Pirot districts). One hundred and fifty questionnaires were distributed and all were completed and processed. Research was conducted from 06.05.2018 until 10.5.2018. Descriptive statistics, correlation and multiple regression analysis methods were used in statistical analysis.

A questionnaire was used as a tool for collecting information. The questionnaire was created based on the idea of Woon et al. (2015) and consists of two parts. The questions in the first part of the questionnaire refer to general customer data (customer size, length of cooperation, purchase frequency). In the second part, questions refer to investigated dimensions of loyalty, i.e., loyalty factors. Loyalty as a dependent variable was measured through four dimensions (questions L1-L4), while independent variables: (1) Customer satisfaction was measured through two dimensions (questions S1-S2), (2) Commitment was measured through three dimensions (PR1-PR3 questions), (3) Trust through three dimensions (PO1-PO3) and Quality perception was also measured through three dimensions (PER1-PER3), which can be seen in Table 1.

\section{RESULTS OF THE RESEARCH AND DISCUSSION}

In order to obtain a better picture of observed indicators value taken into consideration when analyzing the loyalty of customers from the sample, descriptive measures were first determined, which is shown in Table 1. According to these data, the average rating of loyalty provided by customers, measured through four dimensions, is 4.26 , with a standard deviation of 0.87 . The highest average grade was given in answers for Perception of quality questions and it was 4.51 . This estimate also has the lowest standard deviation - 0.67 , which clearly indicates that customers give great importance to the quality of products. The least average rating was given by the Customers to Attachment dimension and it is 4.18 with a standard deviation of 0.83 .

Table 2 provides data for correlation between variables. According to this table, we conclude that there is a strong direct connection between dependent and independent variables, i.e. between customer loyalty and the factors on which it depends. According to Cohen (1988), the value of the Pearson correlation coefficient by 0.3 indicates a weak correlation between phenomena; the value of this coefficient between 0.30 and 0.5 
indicates average, and over 0.5 a strong relationship between phenomena. Bearing in mind the above-mentioned scale for interpreting the strength of the correlation link, we find that the values of the Pearson coefficient of correlation between dependent variable and independent variables are over 0.5 , and we can conclude that this bond is strong. Also, all the coefficients are significant at the level of 0.01 .

Table 1 Descriptive statistics

\begin{tabular}{|c|c|c|c|}
\hline $\begin{array}{l}\text { Question } \\
\text { number }\end{array}$ & Question & $\begin{array}{l}\text { Average } \\
\text { rating }\end{array}$ & $\begin{array}{l}\text { Standard } \\
\text { deviation }\end{array}$ \\
\hline & Customer satisfaction & 4.24 & 0.79 \\
\hline $\mathrm{S} 1$ & Supplier always meets my expectations & 4.13 & .87 \\
\hline \multirow[t]{2}{*}{$\mathrm{S} 2$} & Satisfied with the cooperation with the supplier & 4.35 & .72 \\
\hline & Commitment & 4.18 & 0.83 \\
\hline PR1 & Very attached to supplier & 3.74 & 1.05 \\
\hline PR2 & I will continue to cooperate with supplier & 4.43 & .746 \\
\hline \multirow[t]{2}{*}{ PR3 } & $\begin{array}{l}\text { It is important for me to maintain good business relationships } \\
\text { with supplier }\end{array}$ & 4.39 & .703 \\
\hline & Trust & 4.30 & 0.79 \\
\hline PO1 & Ready to rely on suppliers' products & 4.09 & .89 \\
\hline $\mathrm{PO} 2$ & Have trust in supplier & 4.31 & .84 \\
\hline \multirow[t]{2}{*}{ PO3 } & Consider employees professional and responsible & 4.51 & .65 \\
\hline & Quality perception & 4.51 & 0.67 \\
\hline PER1 & Product quality corresponds to declared & 4.40 & .73 \\
\hline PER2 & Staff is professional & 4.59 & .59 \\
\hline \multirow[t]{2}{*}{ PER3 } & Payment terms are correct & 4.56 & .69 \\
\hline & Customer loyalty & 4.26 & 0.87 \\
\hline L1 & I would recommend suppliers to business partners & 4.41 & .80 \\
\hline L2 & Supplier is my first purchase choice & 4.01 & 1.10 \\
\hline L3 & I plan to stay with supplier in next few years & 4.36 & .77 \\
\hline $\mathrm{L} 4$ & Consider myself a loyal customer of a given supplier & 4.28 & .82 \\
\hline
\end{tabular}
Source: Calculation of authors

Having in mind the data from Table 2, we conclude that we have proved all four hypotheses; we have proved that there is a strong direct correlation between customer loyalty and determination factors. Research results prove that the strongest quantitative match is between customer loyalty and commitment, and the weakest is between customer loyalty and satisfaction. That confirms results of many studies by which satisfaction is necessary but not sufficient condition for the loyal behavior of the buyer (Tikkanen et al., 2000; Ghijsen et al., 2010). Apart from the fact that the customer is satisfied with the company that meets his expectations, the key factor for customer engagement is continuity of cooperation, which shows that both buyer and seller are important and there is a mutual desire to continue and develop it in the future. 
Table 2 Correlation

\begin{tabular}{lccccc}
\hline & $\begin{array}{c}\text { Customer } \\
\text { loyalty }\end{array}$ & Satisfaction & Trust & Commitment & $\begin{array}{c}\text { Quality } \\
\text { perception }\end{array}$ \\
\hline Customer loyalty & 1 & $.541^{* *}$ & $.813^{* *}$ & $.741^{* *}$ & $.656^{* *}$ \\
Satisfaction & & 1 & $.590^{* *}$ & $.611^{* *}$ & $.376^{* *}$ \\
Trust & & & 1 & $.736^{* *}$ & $.613^{* *}$ \\
Commitment & & & & 1 & $.617^{* *}$ \\
Quality perception & & & & & 1 \\
\hline
\end{tabular}

** Level of significance 0.01

Source: Calculation of authors

The mutual relationship of loyalty and the conditioning factor were examined by applying the multiple regression analysis. Based on the data from Table 3, it can be seen that changes in customer loyalty are explained by $72.5 \%$ of changes in independent variables, i.e. with factor changes by which loyalty is conditioned. If stricter criterion is explained, given as a corrected coefficient of multiple determination, it is somewhat smaller, and according to it, the degree of explained variability is $71.8 \%$.

Table 3 Regression

\begin{tabular}{lccc}
\hline & \multicolumn{2}{c}{ Beta } & \multirow{2}{*}{ Sig. } \\
\cline { 2 - 3 } & Unstandardized & Standardized & \\
\hline (Constant) & -.338 & & .228 \\
Satisfaction & .026 & .027 & .636 \\
Trust & .532 & .509 & .000 \\
Commitment & .257 & .232 & .001 \\
Quality perception & .257 & .191 & .001 \\
\hline $\mathrm{R}$ & .852 & & \\
R Square & .725 & & \\
Adjusted R Square & .718 & \\
\hline
\end{tabular}

As shown in Beta Standardized column, Commitment has the highest absolute value, this means that this variable individually has the greatest contribution to the explanation of dependent variable, i.e., Commitment has a dominant influence on customer loyalty. The smallest contribution to changes in dependent variable has Satisfaction. In addition, it should be noted that the significance of this coefficient has not been proven, and this factor should be excluded from further analysis. If we look at the non-standardized values of the regression coefficients, we have another proof of direct dependence between the loyalty and the factors it is conditioned upon. In this way we confirmed the starting hypotheses once again.

\section{CONCLUSION}

Customer satisfaction and loyalty measurement is an important segment of marketing control in order to gather information on what is necessary for customers to repeat their purchase and to decide whether that is sufficient for essential loyalty. Measuring of customer loyalty in the business market is complex and often linked with the subjectivity of researchers. Often, researchers in customer loyalty measurements are focused on 
delivered product / service quality measuring. Repeated purchases can, on the other hand, be an important indicator, but due to preferences, it is not enough to provide essential loyalty. The essence of customer loyalty measuring is getting feedback that determines their long-term repetition of buying and pursuing it in spite of competing pressures.

Customer satisfaction is an important indicator of customer loyalty, but it is not sufficient. Customers may be happy, but they do not have to repeat shopping from the same company. According to that, satisfaction involves cooperation and information exchange with the company. Main requirement is existence of mutual trust with sharing sensitive information in the process of creating value for customers, and developing a long-term relationship with them. Trust creates customer loyalty which explicitly and implicitly means that an open, frequent and honest communication will develop. Such communication increases credibility, reliability and intimacy, and reduces doubt, uncertainty, one-sided orientation and preoccupation. Trust improves customer responsiveness, especially emotional, which increases customer readiness to cooperate and engage more in relationships.

It has been proved in the paper that there is a strong direct correlation between the loyalty factor of the buyer and the loyalty. In this way, the influence of attachment is the strongest. This means that in positioning of long-term relationships, it is necessary to strengthen emotional loyalty aspect of customer loyalty. Such distinction is connected with the long-term orientation of the involved parties and their focus on the achievement of long-term loyalty and goals, as well as the belief that relations will get the desired results. Such attachment is based on trust, readiness to resolve conflict in a friendly manner and support the long-term benefits of relationship.

\section{REFERENCES}

Anderson W. E. \& Mittal, V. (2016). Strengthening the Satisfaction-Profit Chain. Journal of Service Research 3 (2), 107-120.

Bowen, J. T. \& Chen, S. L. M. (2015). Transitioning loyalty programs: A commentary on "The relationship between customer loyalty and customer satisfaction". International Journal of Contemporary Hospitality Management, 27 (3), 415-430.

Caruna, A., Money, A. \& Berthon, P.R. (2000). Service quality and satisfaction: the moderating role of value. European Journal of Marketing, 34 (11/12), 1338-1352.

Cohen, J.W. (1988) Statistical power analysis for the behavior science (2nd edn.). Hillsdale, NJ: Lawrence Erlbuaum Associates.

Diller, H. (2000). Customer Loyalty: Fata Morgana or Realistic Goal? In: Relationship Marketing,Gaining Competitive Advantage through Customer Satisfaction and Customer Retention, Editors: Henning-Thurau, Th., Hansen, U., Springer.

Ghijsen, P., Semeijn, J. \& Ernstson, S. (2010). Supplier satisfaction and commitment: the role of influence strategies and supplier development. Journal of Purchasing and Supply Management, 16 (1), 17-26.

Gruca, S.T. \& Rego, L.L. (2005). Customer Satisfaction, Cash Flow, and Shareholder Value. Journal of Marketing, 69 (3), 115-130.

Jain, S.K. \& Gupta, G. (2004). Measuring Service Quality: SERVQUAL vs. SERVPERF Scales. The Journal for decision makers-Vikalpa, 29 (2), 25-37.

Kotler, P. \& Keller L. K. (2007). A Framework for Marketing Management, third edition, Prentice Hall International, Inc., Upper Saddle Reviver, New Jersey.

Kumar, V., Batista, L. \& Maull, R. (2011). The impact of operations performance on customer loyalty. Service Science, 3 (2), 158-171.

Kumar, V., \& Shah, D. (2004). Building and sustaining profitable customer loyalty for the 21 st century, Journal of Retailing, 80 (4), 317-330.

Kundu, S. \& Datta, S.K. (2015). Impact of trust on the relationship of e-service quality and customer satisfaction, EuroMed Journal of Business, 10 (1), 21-46. https://doi. org/10.1108/EMJB-10-2013-0053 
Lovelock H.C. \& Wirtz J. (2011). Service marketing: people, technology, strategy, $7^{\text {th }}$ edition, McGraw Hill, Prentice Hall.

Mittal V. \& Kamakura, W. (2001). Satisfaction, Repurchase Intent, and Repurchase Behavior: Investigating the Moderating Effect of Customer Characteristics. Journal of Marketing Research, 38 (1), 131-142.

Moorman, C., Despandé, R. \& Zaltman, G. (1993). Factors Affecting Trust in Market Research Relation. Journal of Marketing, 57 (19) 57, 81-101.

Moreira A.C. \& Silva P.M. (2015). The trust-commitment challenge in service quality-loyalty relationships. Internationa Journal of Health Care Quality Assurance, 28 (3), 253-66.

Morgan, R. M. \& Hunt, S. D. (1994). The commitment-trust theory of relationship marketing. Journal of Marketing, 58 (3), 20-38.

Ndubisi, N. O. (2011). Conflict handling, trust and commitment in outsourcing relationship: The Chinese and Indian study. Industrial Marketing Management, 40, 109-117.

Palmatier, R. W. (2008). Interfirm relational drivers of customer value. Journal of Marketing Research, 72 (4), 76-89.

Paquette, S. (2006). Customer Knowledge Management. Idea Group Inc.: 1-7, http://www3.fis.utoronto.ca /phd/paquette/docs/Paquette\%20-\%20Customer\%20Knowledge\%20Management.pdf, (20.05.2010.).

Peppers, D. \& Rogers, M. (2004). Managing Customer Relationships. Strategic Frameworks, John Wiley/Sons, New Jersey.

Pollack, B.L. (2008). The nature of the service quality and satisfaction relationship: empirical evidence for the existence of satisfiers and dissatisfiers. Journal Managing Services Quality, 18 (6), 537-558.

Rauyruen, P. \& Miller, K. (2007). Relationship quality as a predictor of B2B customer loyalty. Journal of Business Research, 60 (1), 21-31.

Rust, R. T. \& Ming-Hui, H. (2014). Handbook of Service Marketing Research. Cheltenham: Edward Elgar.

Tikkanen, H., Alajoutsijärvi, K. \& Tahtinen, J. (2000). The Concept of Satisfaction in Industrial Markets: A Contextual Perspective and a Case Study from the Software Industry. Industrial Marketing Management, 29 (4), 373-386.

Trasorras, R., Weinstein, A. \& Abratt, R. (2009). Value, satisfaction, loyalty and retention in professional services. Marketing Intelligence \& Planning, 27 (5), 615-632.

Ulaga, W., \& Eggert, A. (2006). Relationship value and relationship quality: broadening the nomological network of business-to-business relationships. European Journal of Marketing, 40 (3/4), 311-327.

Veljković, S. (2009). Marketing usluga [Marketing of Services]. Beograd: CID Ekonomskog fakulteta u Beogradu

Wilson, A., Zeinthaml, A.V., Bithner, J.M. \& Gremler, D.D. (2012). Services Marketing: Integrating Customer Focus Across the Firm. McGraw Hill.

Woon, C.L., Kee, L.K., Hwee, T. G., Lee, T. L. \& Cheng, T.S. (2015). Factors Influencing Customer Loyalty in Airline Industry in Malaysia, Retrieved from: http://eprints.utar.edu.my/1802/1/BAC-2015-12068201.pdf, Accessed on: 20 March 2018.

\section{FAKTORI KOJI UTIČU NA LOJALNOST KUPACA NA POSLOVNOM TRŽIŠTU - EMPIRIJSKA STUDIJA U REPUBLICI SRBIJI}

U savremenim uslovima poslovanja koje karakterišu zahtevi za ostvarenje superiornih profitnih marži, satisfakcija i lojalnost kupca su postali osnovni poslovni prioriteti preduzeća. Sposobnost preduzeća da ostvari visoku stopu lojalnosti kupaca u uslovima intenzivne konkurencije uslovljena je isporukom usluge superiornog kvaliteta, ali i stvaranjem pozitivnog ukupnog iskustva kupca sa preduzećem. Takva situacija podrazumeva razvijanje odnosa koji se zasnivaju na poverenju i privrženosti kupca preduzeću i njegovim markama. Cilj autora u radu je da istraže uticaj satisfakcije, poverenja, privrženost kupca i percipiranog kvaliteta usluga na stepen ostvarene lojalnost. Empirijsko istraživanje je realizovano na uzorku malih i srednjih preduzeća u cilju istraživanja povezanosti lojalnosti i faktora kojima je ona uslovljena. Statisticka analiza zasnovana je na primeni multivarijacionih tehnika koje su omogućile simultanu analizu međusobnog odnosa između identifikovane četiri nezavisne varijable na zavisnu varijablu, odnosno na stepen lojalnosti kupca. U tom smislu je korišćena višestuka regresiona $i$ korelaciona analiza.

Ključne reči: potrošači, lojalnost, satisfakcija, poverenje, privrženost, poslovno tržište 